\title{
Luottamuksen kadottaminen ja uudelleen löytäminen
}

Richard Sennett: Uuden kapitalismin kulttuuri. Suom. Kaisa Koskinen. Vastapaino 2007.

Paul Adler \& Charles Hecksher (toim.) (2006). The Firm and a Collaborative Community. Reconstructing Trust in the Knowledge Economy. Oxford University Press.

Zygmunt Bauman kuvaa menneen maailman byrokraattista organisaatiota avioliittometaforan avulla. Fordilaisena aikana työ ja pääoma olivat yhdistyneet myötä- ja vastoinkäymisissä, "kunnes kuolema heidät erotti. Tehdas oli heidän yhteinen asuntonsa - samanaikaisesti asemasodan näyttämö sekä toiveiden ja unelmien tyyssija”. Nyt eri alojen työsuhteet ovat kestävän liiton sijasta "kunnes toisin ilmoitetaan” -suhteita (Bauman 2002, 174-175).

Tunnettu amerikkalaissosiologi Richard Sennett kuvaa uudessa teoksessaan byrokraatti- sen, Max Weberin nimeämän "rautahäkkimäisen" organisaatiomallin purkautumista. Instituutioiden hapertuminen ei ole odotuksista huolimatta lisännyt yhteisöllisyyttä, sitä vastoin muutoksella on ollut kolmenlaisia vaikutuksia: lojaalisuus instituutiota kohtaan hapertuu, työntekijöiden keskinäinen luottamus heikkenee sekä instituution kokonaisuutta koskeva tieto vähenee.

Luottamuksella on vaikutuksia työntekijöiden hyvinvointiin. Työpaineita on, ja ylitöitä tehdään sekä matalan että korkean vastavuoroisen luottamuk- sen oloissa, mutta matalan luottamuksen organisaatioissa työpaineet ja yli kymmentuntiset työpäivät vaikuttavat työntekijöihin selvästi haitallisimmin. Luottamus tai sen puute näkyy myös työttömien hyvinvoinnissa. Matti Kortteinen (1999, 349) havaitsi yhteyden suomalaisten työttömien terveydentilan ja heidän kokemansa luottamuksen välillä. Mitä laskelmoivampana ja epäluotettavampana työtön koki maailman, sitä nopeammin ja voimakkaammin hän sairastui somaattisesti tai psyykkisesti.

Sennett ei varsinaisesti ihannoi byrokraattista ja hierarkkista organisaatiomallia, mutta näkee kuitenkin, että sellaisen osana työntekijöillä oli mahdollisuus nähdä elämänuransa ennustettavina ja ymmärrettävinä askeleina 
ja yhtenäisenä kertomuksena. Juha Siltalan nimeämän tämänhetkisen työntekijöiden "rauta-ajan" ennakoimattomuus on tuonut irrallisista episodeista koostuvan aikakäsityksen. USA:ssa verrattiin yliopistoopiskelijoiden urasuuntautuneisuutta 1970-luvulla ja 2000-luvun alussa. Molempia opiskelijaryhmiä leimasi kunnianhimo, mutta selvä ero havaittiin tavoitteiden aikaperspektiivissä. 1970-luvun urasuuntautujat painottivat pitkän aikavälin strategisia tavoitteita, 2000-luvun ryhmä välittömiä mahdollisuuksia. Edelliset pystyivät verbalisoimaan tavoitteitaan varsin selkeästi, mutta jälkimmäisten oli vaikea löytää tavoittelemalleen sanoja.

BBC:n esimerkkiin tukeutuen Sennett väittää, että osaaminen on monin paikoin jo alkanut merkitä kykyä tehdä uudenlaista pikemmin kuin tukeutua siihen minkä jo osaa. On musertavampaa kuulla arvio "sinulla ei ole potentiaalia" verrattuna palautteeseen: "Teit virheen”. Tarpeettomuuden tunteen vaaniessa työntekijän on osattava myydä itsensä "hyvänä tyyppinä”, moniosaajana ja tiimipelurina. Työelämän tutkija Jussi Vähämäen mukaan tällaisia henkilöitä nimitettiin ennen helppoheikeiksi. Joustavan organisaation ihannetyöntekijä on "kaikkialla kaikkien kanssa yhtaikaa” ja tulee toimeen kenen kanssa tahansa lyhytaikaisissa tiimeissä. Työelämän lyhytjännitteisyyden ja teeskennellyn innostuksen aikaansaamaa luonteen rapautumista Sennett on kuvannut mieleenpainuvasti aiemmassa kirjassaan (Sennett 2002).

Konsulttikohelluksen ja pinnallisen "moniosaamisen" vas- takohdaksi esitetään työn tekemistä hyvin sen itsensä vuoksi. Emme tiedä, miten paljon viulunrakentaja Niccolo Amati (15961684) verkottui tai toteutti itseään työssään, mutta tunnemme hänen työnsä ainutlaatuiset tulokset. Työn tulos itsessään oli merkittävä. Alkuteoksessa Sennett käyttää kunniallisuudesta ja ammattiylpeydestä viestivää, joskin nykytyöelämässä vanhahtavan kuuloista termiä craftsmanship. Kun Helsingin Hietalahden telakalla vielä rakennettiin Karibian loistoristeilijöitä, rakenteilla olevan laivan kylkeen oli ripustettu banderolli Finnish Craftsmanship. Tarinan mukaan se käännettiin monesti suomalaiseksi ammattimieslaivaksi.

Ammattimaisuus ei aina ole ollut itsestään selvä asenne. Keskiaikaisissa ammattikunnissa arvostettu asema ei perustunut työn laatuun ja ammatillisuuteen, vaan perittyyn asemaan ja hierarkiaan. Tästä kuvanveistäjä Benvenuto Cellini (1500-1571) arvosteli ankarasti firenzeläistä kultaseppien kiltaa, johon hän nuorena liittyi. Tavallaan Cellinin arvostelu näytti jo tietä uudempaan järjestelmään, jossa yksilön arvonanto perustui henkilökohtaiseen osaamiseen.

Itsekuri ja itsekriittisyys ovat ammattilaisen ominaisuuksia. Hyvin tehty työ palkitsee riippumatta, saako siitä kiitosta tai onko työnteko aina sisällöllisesti palkitsevaa. Siten ammattimaisuus ei liity vain luoviin ja paljon koulutusta vaativiin tehtäviin. Ammattilainen on perehtynyt ja myös kiintynyt liikaa työhönsä pystyäkseen nopeisiin vaihdoksiin, joita konsultit ja "muutosjohtajat" odottaisivat.

Miten suomalaiset työelämän tutkijat ovat ottaneet vastaan ammatillisuuden käsityksen vastakohtana pinnalliselle konsulttikohellukselle? Sennettiä on pidetty vanhanaikaisena ja romanttisena, työtä yksilöllistävänä, koska nykyisin ammattilaisen pitää jatkuvasti "verkottua joka suuntaan” (Saksa 2006).

\section{Voiko luottamus silti syn- tyä?}

Vaikka monet valittavat yhteisöllisyyden rapautumista, harvat kaivannevat perinteistä yhteisöä, jossa horisontaalisetkin sosiaaliset suhteet - esimerkiksi lääkäri-potilas tai mies-vaimo perustuivat sosiaaliseen rooliin ja systeemiin pikemmin kuin vuorovaikutukseen ja neuvoteltavuuteen. Toisaalta, jos perinteisten sidosten kadottua tukeudutaan yksin markkinavoimiin, ajaudutaan vieraantumiseen (Marx), anomiaan (Durkheim), kansalaisosallistumisen puutteeseen (Putnam), henkiseen tasapainottomuuteen (Fromm), luonteen rapautumiseen (Sennett) ja moraalisen suunnan hämärtymiseen. Karl Polanyin (1944) mukaan vapaasti toimiessaan markkinamylly - tai runoilija William Blaken sanoin saatanallinen mylly - jauhaa sokeasti hajalle yhteiskunnan, joka myllyn on pystyttänyt.

Paul Adlerin ja Charles Heckscherin toimittaman teoksen The Firm and a Collaborative Community aiheena on yhteisöllisyyden nousu suuryrityksissä. Kirjaan on koottu psykologien, sosiologien sekä talous- ja organisaatiotutkijoiden artikkeleita eri alojen yritysten sisäisestä ja niiden välisestä yhteistoiminnallisuudesta ja luottamuksesta. Kirja jakautuu neljään osaan. Ykkösosassa raja-taan yhteistoiminnallisen yhteisön 
käsite, toisessa osassa käsitellään yrityksen sisäisiä ja kolmannessa yritysten välille syntyneitä yhteistoiminnan muotoja. Viimeisessä osassa tarkastellaan yhteisön syntyyn johtavia muutosprosesseja.

Satasivuisessa avausartikkelissaan Towards Collaborative Community toimittajat jaottelevat työelämän tutkijat kolmeen leiriin suhteessa yhteisöllisyyteen. Menetetyn yhteisön traagista näkökulmaa edustaa heidän mukaansa muun muassa Richard Sennett, vaikka hän ei viime vuosina ole kirjoittanut perinteisen yhteisöllisyyden vaan byrokraattisen ja modernin rautahäkkiorganisaatiomuodon katoamisesta. Toisessa eli konservatiivileirissä toivo pannaan perinteisen yhteisön hyveiden elvyttämiseen.

Kolmas leiri, johon Adler ja Heckscher itse samastuvat, näkee luottamuksen sekä solidaarisuuden ja autonomian samanaikaista nousua dynaamisissa, vaihtuvissa ja moninaisissa suhteissa. Ongelmana he näkevät viimemainitun näkökulman jäämisen usein kovin abstraktille ja filosofiselle tasolle. He samoin kuin kirjan muut kirjoittajat pyrkivät ankkuroimaan oman näkökulmansa käytännön havaintoihin. Joitakin menestyksekkäitä USA:n suuryrityksiä tarkastelleessaan Adler, Heckscher ja kumppanit ovat löytäneet jaettua keskinäisen riippuvuuden etiikkaa, joka eroaa kauan vallinneesta byrokraattisen lojaalisuuden ja individualismin oudosta toisiinsa kietoutumisesta.

Adlerin ja Heckscherin pääväittämän mukaan tietointensiivisessä taloudessa lojaalisuus ja luottamus ovat tärkeämpiä kuin koskaan, ja uuden tyyppinen luottamus olisikin - toden totta - hitaasti ja paikoin nousemassa. On selvää, että voittoa tuottavassa yrityksessä on jo lähtökohtaisesti paljon yhteisöllisyyden esteitä. Yhteisöllisyyden muotoja on vaikea tunnistaa byrokratian ja markkinavoimien samanaikaisessa puristuksessa. Kirjoittajat torjuvat kuitenkin syytteet "pollyannamaisuudesta”. Kehitys ei voi olla suoraviivaista, vaan usein vaikeasti tunnistettavaa siksakliikettä. Adler ja Heckscher antavat uudelle yhteisöllisyydelle nimen yhteistoiminnallinen yhteisö (collaborative community).

Yhteistoiminnallinen yhteisö muodostuu, kun ihmiset kokoontuvat yhteen luomaan jaettua arvoa. Tällainen on mahdollista niissä yhteiskunnissa, joissa taloudellisen tuotannon huomattava osa syntyy tiedon ja monien asiantuntijoiden yhteistyön pohjalta. Yhteistoiminnallisessa yhteisössä tuotettu jaettu arvo on erilaista kuin perinteisissä yhteisöissä, joissa arvot ovat ikuisia eikä niiden syntymiseksi tarvita erityisiä ponnistuksia. Eroa on myös moderniin yhteisöön, jossa arvot ovat siirtyneet julkisesta sfääristä yksilöille, ja yhteisö on vain paikka, jossa yksilöt toteuttavat omia intressejään. Modernissa byrokraattisessa yhteisössä yhteistyö on vain satunnainen yksilöiden intressien toteutuksen sivutuote (s. 20-21).

Uudenlainen luottamus on joustavampaa ja laaja-alaisempaa kuin perinteisessä yhteisöllisyydessä. Siten ylittyy Ferdinand Tönniesin (1855-1936) tunnettu jaottelu perinteiseen Gemeinschaftiin ja modernin teollisen ajan Gesellschaftiin. Kirjoitajien mukaan kontribuuti- oon ja yhteistoimintaan perustuva etiikka ei rakennu byrokraattisen organisaation tavoin pitkäaikaiseen lojaalisuuteen vaan kulloisenkin yhteistyön kohteen kautta syntyvään lojaalisuuteen. Zygmunt Bauman ehkä kuvaisi tällaista luottamusta ja yhteistyön moraalia "kunnes toisin ilmoitetaan" suhteisiin perustuvaksi.

\section{Lähteet}

Bauman, Z. (2002). Notkea moderni. Tampere: Vastapaino.

Kortteinen, M. (1999). Sosiaalinen luottamus työttömien selviytymisessä - keskustelua Anthony Giddensin kanssa. Teoksessa S. Näre (toim.). Tunteiden sosiologia, osa 2: Historiaa ja sääntelyä. Helsinki: SKS.

Polanyi, K. (1944). The Great Transformation: The Political and Economic Origins of Our Time. Boston: Beacon Press.

Saksa, M. (2006). Brittitutkija: Ammattimies ei enää pärjää työelämässä. Helsingin Sanomat/talous 17.7.

Sennett, R. (2002). Työn uusi järjestys. Miten kapitalismi kuluttaa ihmisen luonnetta. Tampere: Vastapaino.

JUSSI ONNISMAA 